\title{
Pengaruh Latar Belakang Warna pada Objek Gambar terhadap Hasil Ekstraksi Sinyal EEG
}

\author{
Catur Atmaji*1, Zandy Yudha Perwira ${ }^{2}$ \\ ${ }^{1}$ Departemen Ilmu Komputer dan Elektronika, FMIPA UGM, Yogyakarta, Indonesia \\ ${ }^{2}$ Prodi Elektronika dan Instrumentasi, DIKE, FMIPA UGM, Yogyakarta, Indonesia \\ e-mail: *11 catur_atmaji@ugm.ac.id, ${ }^{2}$ zandy.yudha.p@mail.ugm.ac.id
}

\begin{abstract}
Abstrak
Pada penelitian ini, telah dilakukan pengamatan pada perbedaan kualitas ciri dari data rekam EEG sebagai hasil pelatihan dari subjek. Ciri data rekam EEG diekstrak dengan dua metode, yaitu RMS pada detik ke-0,5 hingga ke-5 dan rerata PSE pada frekuensi 20 hingga $40 H z$. Seluruh data terdiri dari 4 kanal perekaman dan menghasilkan hasil klasifikasi yang baik pada suatu jaringan syaraf tiruan, dimana masing-masing memiliki akurasi data latih mencapai lebih dari 90\%. Namun demikian, hasil berbeda diperoleh ketika sistem yang telah dilatih diujikan pada data uji selain data latih tersebut. Hasil pengujian menunjukkan bahwa dua sistem yang dilatih dengan data latih berupa objek dengan latar belakang warna menghasilkan akurasi yang lebih tinggi dibanding dengan dua sistem lain yang dilatih dengan data latih berupa objek tanpa latar belakang warna, yaitu masing-masing 63,98\% dan 60,22\% berbanding 59,68\% dan 56,45\%. Dari penggunaan ciri pada sistem klasifikasi berupa jaringan syaraf tiruan, dapat disimpulkan bahwa pelatihan sistem dengan data rekam EEG yang berasal dari visualisasi objek tak berwarna dengan latar belakang warna menghasilkan ciri yang lebih baik dibanding dengan visualisasi objek tak berwarna tanpa latar belakang warna.
\end{abstract}

Kata kunci-EEG, visual evoked potential, pengaruh warna, ekstraksi ciri

\begin{abstract}
In this study, observation on the differences in features quality of EEG records as a result of training on subjects has been made. The features of EEG records were extracted using two different methods, the root mean square which is acquired from the range between 0.5 and 5 seconds and the average of power spectrum estimation from the frequency range between 20 and $40 \mathrm{~Hz}$. All of the data consists of a 4-channel recording and produce good quality classification on artificial neural network, with each of which generates training data accuracy over $90 \%$. However, different results are occured when the trained system is tested on other test data. The test results show that the two systems which are trained using training data with object with color background produce higher accuracy than the other two systems which are trained using training data with object without background color, $63.98 \%$ and $60.22 \%$ compared to $59.68 \%$ and $56.45 \%$ accuracy respectively. From the use of the features on the artificial neural network classification system, it can be concluded that the training system using EEG data records derived from the visualization of object with color background produces better features than the visualization of object without color background.
\end{abstract}

Keywords - EEG, visual evoked potential, color effect, feature extraction 


\section{PENDAHULUAN}

S Sejak ditemukan adanya aktivitas elektris pada otak manusia oleh Richard Canton,

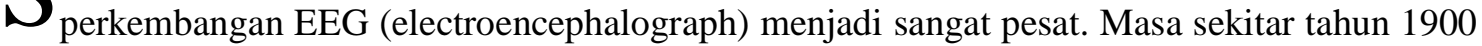
merupakan masa dimana EEG menjadi bagian yang tak terpisahkan dari analisis kesehatan yang berkaitan dengan otak. Terkait dengan hal tersebut, banyak dilakukan analisis EEG pada penderita epilepsi [1].

Pada awalnya, analisis rekaman EEG menunjukkan bahwa terdapat bentuk gelombang tertentu yang disebut sebagai spike yang muncul pada beberapa perekaman EEG. Pada penderita epilepsi, bentuk spike yang muncul berbeda dengan bentuk spike yang muncul pada orang sehat. Dari konsep spike tersebut, banyak dirumuskan metode deteksi maupun klasifikasi bentuk spike dari rekaman EEG [2-4].

Penjelasan mengenai event-related potentials (ERP) pada tahun 1964 selanjutnya memberikan gambaran lebih jelas kepada para pemerhati EEG dalam kaitannya dengan aktivitas manusia. ERP yang secara umum muncul ketika manusia mengalami rangsangan membuka jalan bagi suatu konsep yang disebut sebagai brain-computer interface (BCI). Perancangan BCI bertujuan jangka panjang untuk menghubungkan otak manusia melalui sinyal EEG agar dapat berkomunikasi langsung dengan sistem, umumnya sistem kendali.

Kunci dari analisis sinyal EEG adalah pada ekstraksi ciri dan metode yang digunakan untuk mengolah ciri tersebut menjadi sistem yang dibutuhkan. Sistem untuk keperluan medis seperti deteksi spike serta sistem untuk keperluan kendali memerlukan ciri yang bagus untuk dapat diterapkan dalam sistem pengenalan maupun sistem kendali yang digunakan [5-7]. Ciri yang tidak bagus akan mempengaruhi performa dari sistem yang digunakan.

Salah satu hal yang menyebabkan sulitnya ekstraksi ciri pada sinyal EEG adalah berasal dari tidak baiknya sinyal EEG itu sendiri. Atau dapat dikatakan bahwa respon sinyal EEG terhadap beberapa kondisi yang ditentukan memiliki perbedaan yang tidak terlalu signifikan. Beberapa penelitian terkini telah dilakukan untuk mengamati pengaruh stimulus warna yang diberikan kepada seseorang terhadap sinyal EEG [8-10]. Perbedaan yang muncul dari beberapa stimulus warna memberikan hasil sinyal EEG yang cukup berbeda. Hasil tersebut memberikan gambaran bagi peneliti untuk melakukan studi pengaruh warna terhadap sinyal EEG sebagai hasil dari fokus subjek pada objek yang pada dasarnya tidak berwarna.

\section{METODE PENELITIAN}

\subsection{Akuisisi Data}

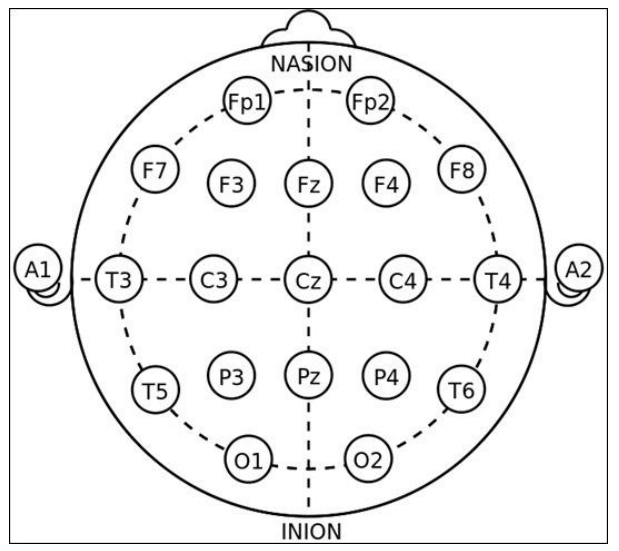

Gambar 1 Sistem Internasional 10-20 sebagai acuan penempatan elektroda untuk membaca gelombang otak [1]

Pada persiapan perekaman data, digunakan piranti perekam sinyal EEG berupa OpenBCI Cyton. Pada proses pengambilan data, digunakan sensor berupa elektroda jenis gold

IJEIS Vol. 7, No. 2, October $2017: 161-172$ 
cup dengan referensi yang dipasangkan pada kedua daun telinga. Data EEG yang dihasilkan berupa sinyal dengan frekuensi pencuplikan sebesar $250 \mathrm{~Hz}$.

Akuisisi sinyal EEG dilakukan pada 4 kanal yang sesuai dengan standar internasional 10-20 seperti ditunjukkan pada Gambar 1. Standar tersebut menunjukkan lokasi-lokasi peletakan elektroda untuk perekaman EEG pada kepala. Bersesuaian dengan standar tersebut, pada penelitian ini elektroda sebagai sensor EEG ditempatkan pada 4 kanal (kanal parietal dan central), dimana kanal-kanal tersebut berhubungan dengan imajinasi gerak dari seseorang (motor imagery), yaitu sebagai berikut:
1. Kanal FP1
2. Kanal FP2
3. Kanal C3
4. Kanal C4

\subsection{Prosedur Eksperimen}

Dalam penelitian ini, digunakan dua kelas gambar untuk satu kali sesi pengambilan data rekam, dimana dua kelas gambar tersebut saling berlawanan untuk memperkuat imajinasi dari subjek. Berkaitan dengan maksud tersebut, digunakan dua pasang gambar sebagai objek, yaitu gambar atas-bawah dan kiri-kanan, dimana subjek akan mengamati salah satu dari kedua pasang gambar tersebut. Terkait dengan latar belakang warna, dilakukan perbandingan hasil perekaman sinyal EEG ketika subjek mengamati objek dengan latar belakang putih (tak berwarna) dengan objek berlatar belakang warna yang berbeda untuk dua kelas gambar. Masing-masing pasangan objek tanpa latar belakang warna dan dengan latar belakang warna yang digunakan pada penelitian ini ditunjukkan pada Gambar 2 dan Gambar 3.
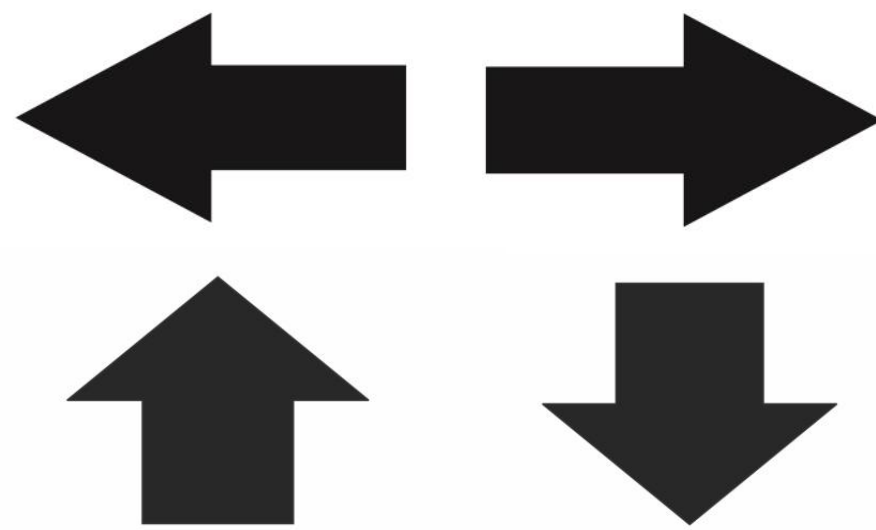

Gambar 2 Dua pasang gambar sebagai objek tanpa latar belakang warna

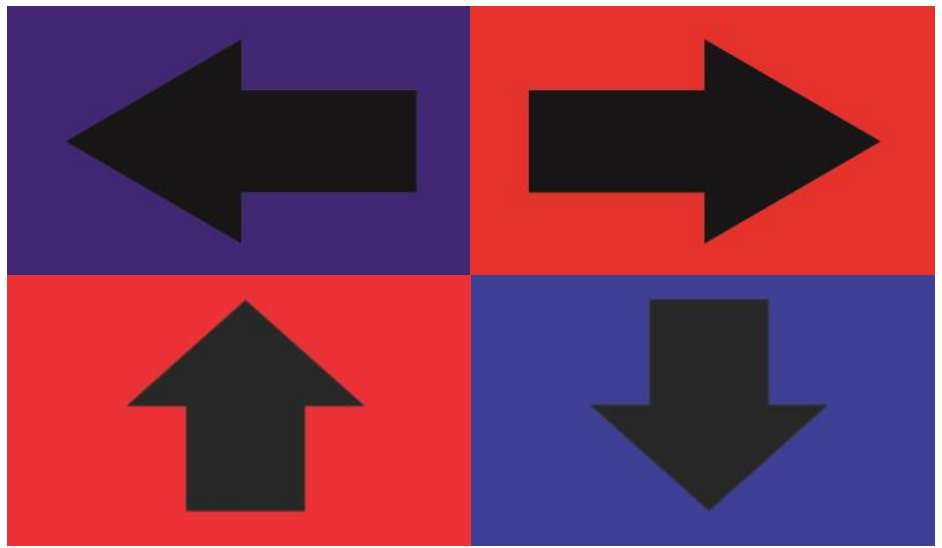

Gambar 3 Dua pasang gambar sebagai objek dengan latar belakang warna 
Untuk prosedur pengambilan data, dalam satu kali sesi pengambilan data dari subjek, ditampilkan objek gambar secara bergantian antara objek kelas 0 , kelas 1 , dan jeda. Objek kelas 0 berupa anak panah ke kiri atau anak panah ke atas, sedang kelas 1 berupa anak panah kanan atau anak panah ke bawah. Pada satu kali sesi pengambilan data, objek yang ditampilkan berupa pasangan horisontal saja (kiri dan kanan) atau vertikal saja (atas dan bawah). Dua variasi tersebut dilakukan dengan tujuan untuk memberikan variasi data dengan dua kelas dan tetap memiliki makna yang sangat berlawanan.

Secara keseluruhan terdapat 4 pasangan objek yang divisualisasikan kepada subjek, terkait dengan gambar objek dan latar belakangnya. Setiap subjek akan melakukan perekaman dengan mengamati keempat pasangan tersebut secara bergantian, tidak secara berurutan. Jeda antara satu sesi perekaman dengan sesi berikutnya diberikan agar sinyal EEG yang dihasilkan tidak saling mempengaruhi antara satu sesi dengan sesi yang lain. Dalam hal ini, diberikan kode untuk mempermudah pengamatan data, sesuai dengan yang ditampilkan pada Tabel 1.

Tabel 1 Jenis-jenis objek untuk visualisasi

\begin{tabular}{|c|c|l|}
\hline No & Kode Visualisasi & \multicolumn{1}{c|}{ Keterangan } \\
\hline 1 & PH & Objek anak panah horisontal, latar belakang tak berwarna \\
\hline 2 & PV & Objek anak panah vertikal, latar belakang tak berwarna \\
\hline 3 & WH & Objek anak panah horisontal, latar belakang berwarna \\
\hline 4 & WV & Objek anak panah vertikal, latar belakang berwarna \\
\hline
\end{tabular}

Secara terurut, perekaman akan terdiri dari jeda awal, visualisasi objek kelas 0 , jeda, objek kelas 2, jeda, dan seterusnya hingga berulang tiga kali. Jeda dalam hal ini divisualisasikan dengan gambar putih polos. Visualisasi objek dalam ditampilkan dalam sebuah layar LCD dengan dimensi 16" dan resolusi layar adalah 720p dengan subjek menghadap ke sisi ruangan yang memiliki tembok berwarna putih polos. Durasi visualisasi setiap objek adalah sebagai berikut:

$\begin{array}{ll}\text { Jeda } & : 3 \text { detik } \\ \text { Kelas 0 } & : 6 \text { detik } \\ \text { Kelas 1 } & : 6 \text { detik }\end{array}$

\subsection{Pra pengolahan data}

Berdasar peralatan yang digunakan untuk perekaman data, terdapat gangguan sinyal dengan frekuensi sebesar $50 \mathrm{~Hz}$ yang berasal dari masalah kelistrikan seperti halnya potensi munculnya bias DC yang diwakili oleh frekuensi yang sangat rendah. Sedang frekuensi sinyal EEG yang diamati berada pada seluruh rentang ritme gelombang EEG, termasuk delta, teta, alfa, beta, dan gama, yang dapat berada pada jangkauan frekuensi $0-50 \mathrm{~Hz}$. Terkait dengan hal tersebut, dilakukan dua tahap penapisan digital, yaitu penapisan notch pada frekuensi $49-51$ $\mathrm{Hz}$ untuk menapis derau akibat kelistrikan dan tapis lolos tengah $0,5-50 \mathrm{~Hz}$ untuk meloloskan seluruh frekuensi yang berpotensi diamati pada sinyal EEG yang terekam. Kedua tapis tersebut dirancang dengan tapis Butterworth orde-2 seperti ditunjukkan pada persamaan (1) dan persamaan (2).

$$
\begin{aligned}
& H_{\text {notch }}=\frac{0,97-1,19 z^{-1}+2,29 z^{-2}-1,19 z^{-3}+0,97 z^{-4}}{1-1,21 z^{-1}+2,30 z^{-2}-1,17 z^{-3}+0,93 z^{-4}} \\
& H_{B P}=\frac{0,20-0,40 z^{-2}+0,20 z^{-4}}{1-2,36 z^{-1}+1,94 z^{-2}-0,78 z^{-3}+0,20 z^{-4}}
\end{aligned}
$$




\subsection{Ekstraksi ciri pada ranah waktu}

Secara konsep, rangsangan pada seseorang mempengaruhi bentuk dari gelombang otak sesaat setelah rangsangan tersebut muncul hingga paling lama sampai pada 10 detik kemudian (Sanei and Chambers, 2007). Pengaruh yang lama tersebut disebut sebagai slow cortical potential (SCP). Berdasar pada konsep tersebut, dilakukan ekstraksi ciri dari sinyal EEG yang telah direkam dengan mengambil nilai RMS (root mean square) dari data selama 4,5 detik, dari detik ke-0,5 sampai detik ke 5. Maka, setiap data pada kanal tertentu akan diwakili oleh ciri RMS pada ranah waktu sesuai dengan persamaan (3).

$$
\bar{x}_{i}=\sqrt{\frac{1}{N} \sum_{i=1}^{N} x_{i}^{2}(n)}
$$

\subsection{Ekstraksi ciri pada ranah frekuensi}

Aktivitas gelombang otak yang direkam sebagai EEG pada seseorang sangat erat kaitannya dengan frekuensi dari gelombang otak. Frekuensi rendah berhubungan dengan aktivitas yang sangat santai sampai tidur, sedangkan frekuensi tinggi berhubungan dengan fokus dan aktivitas tinggi.

Pada penelitian ini, data rekam EEG yang diamati adalah pada frekuensi tinggi, yaitu dari $20-40 \mathrm{~Hz}$, sesuai dengan pengamatan yang dilakukan pada penelitian terdahulu [11]. Pengamatan pada ranah frekuensi dilakukan dengan menggunakan estimasi spektrum daya (power spectrum estimation=PSE) yang dirumuskan oleh Welch seperti yang ditunjukkan pada persamaan (4)[12]. Dari hasil analisis frekuensi tersebut, ciri frekuensi yang diambil adalah rerata dari hasil estimasi tersebut pada jangkauan frekuensi $20-40 \mathrm{~Hz}$ sesuai dengan rumusan pada persamaan (5).

$$
\begin{gathered}
A_{k}(n)=\frac{1}{L} \sum_{j=0}^{L-1} X_{k}(j) W(j) e^{-2 k i j n / L} \\
\bar{y}_{i}=\frac{1}{F} \sum_{f=20}^{40} y_{i}(f)
\end{gathered}
$$

\subsection{Analisis ciri}

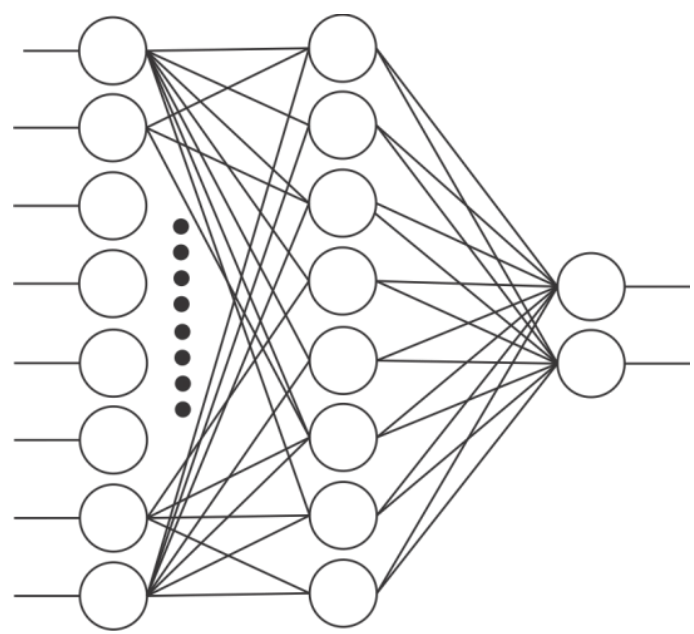

Gambar 4 Arsitektur jaringan syaraf tiruan dengan 8 masukan, 8 titik tersembunyi, dan 2 luaran 
Hasil ekstraksi ciri dari sinyal EEG yang telah didapatkan, kemudian dinilai secara kuantitatif untuk mengamati pengaruh latar belakang warna dalam hal memperkuat ciri atau secara kuantitatif memberikan nilai ciri yang lebih berbeda daripada tanpa latar belakang warna. Untuk melakukannya, digunakan jaringan syaraf tiruan dengan arsitektur multilayer perceptron yang memiliki dua kelas luaran.

Pada Gambar 4, ditampilkan arsitektur jaringan syaraf tiruan yang dirancang memiliki 8 titik masukan yang berasal dari ciri ranah waktu dan ciri ranah frekuensi untuk masing-masing dari empat kanal perekaman. Pada lapisan tersembunyi, digunakan 8 titik sedang pada lapisan luaran digunakan dua titik, masing-masing akan aktif untuk mewakili satu kelas luaran.

\section{HASIL DAN PEMBAHASAN}

\subsection{Subjek penelitian}

Pada penelitian ini, perekaman dilakukan pada enam subjek perekaman dimana seluruh subjek berjenis kelamin laki-laki pada rentang usia 21 hingga 2 tahun seperti ditunjukkan pada Tabel 2. Seluruh subjek memiliki pekerjaan yang sama, yaitu sebagai mahasiswa. Kondisi mata pada subjek dicatat karena objek adalah berupa visualisasi gambar, dimana diharapkan seluruh subjek tidak mengalami gangguan penglihatan atau terkoreksi penglihatannya ketika melakukan seluruh sesi perekaman.

Tabel 2 Deskripsi subjek

\begin{tabular}{|c|c|c|c|c|c|c|}
\hline \multirow{2}{*}{ No } & \multirow{2}{*}{$\begin{array}{l}\text { Usia } \\
\text { (tahun) }\end{array}$} & \multirow{2}{*}{$\begin{array}{c}\text { Jenis } \\
\text { Kelamin }\end{array}$} & \multicolumn{2}{|c|}{ Kondisi Mata } & \multirow{2}{*}{ Kacamata } & \multirow{2}{*}{ Pekerjaan } \\
\hline & & & Kanan & Kiri & & \\
\hline 1 & 25 & Laki-laki & $-3,0$ & $-3,0$ & Tidak & Mahasiswa \\
\hline 2 & 24 & Laki-laki & $-2,5$ & $-2,0$ & $\mathrm{Ya}$ & Mahasiswa \\
\hline 3 & 21 & Laki-laki & $-2,5$ & $-2,5$ & $\mathrm{Ya}$ & Mahasiswa \\
\hline 4 & 21 & Laki-laki & 0,0 & 0,0 & Tidak & Mahasiswa \\
\hline 5 & 22 & Laki-laki & $-0,5$ & $-0,5$ & Ya & Mahasiswa \\
\hline 6 & 21 & Laki-laki & 0,0 & 0,0 & Tidak & Mahasiswa \\
\hline
\end{tabular}

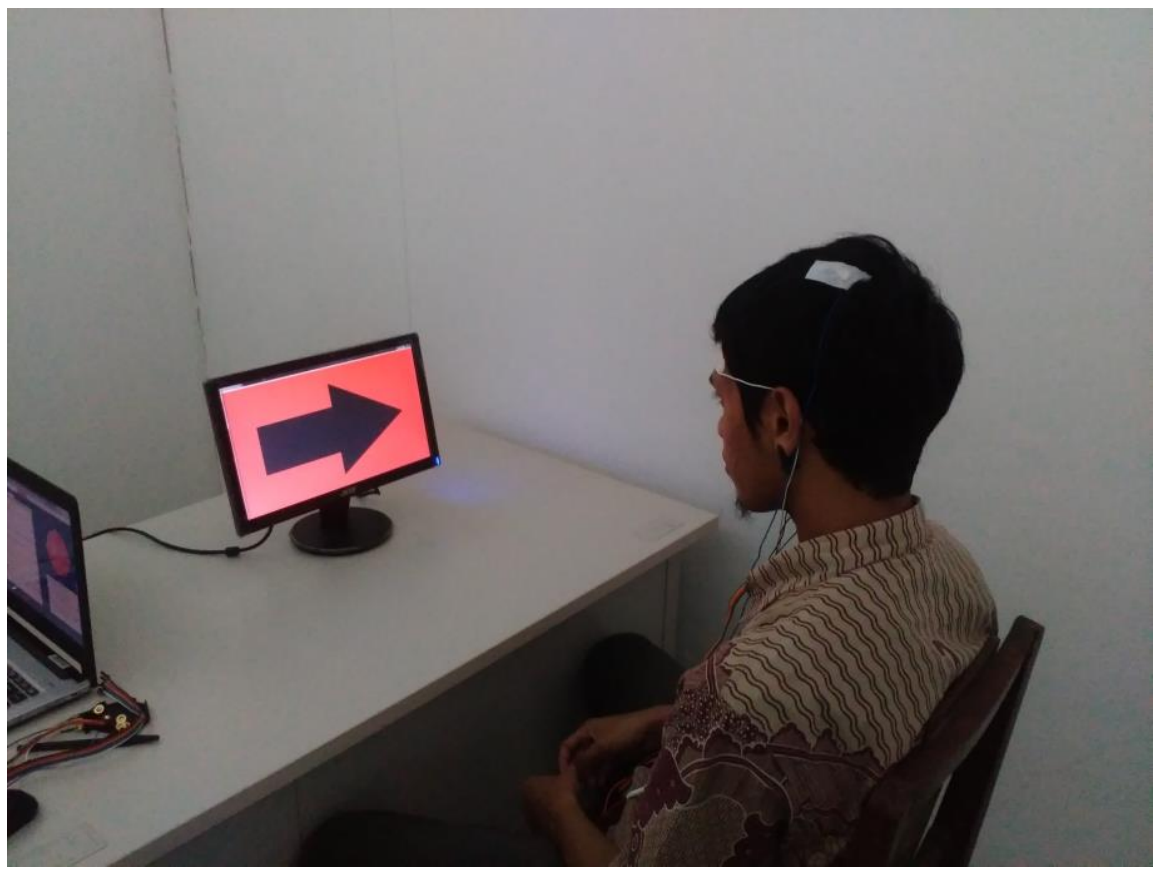

Gambar 5 Contoh proses pengambilan data 
Pada Gambar 1, ditunjukkan salah satu proses perekaman data pada salah seorang subjek. Gambar tersebut menunjukkan jenis data yang digunakan pada sesi tersebut adalah arah horisontal dengan latar belakang warna (WH). Secara keseluruhan, durasi visualisasi objek seperti ditunjukkan pada subbab (2.2) dimana satu kali sesi pengambilan, objek divisualisasikan sebanyak tiga kali. Dengan demikian, urutan visualisasi adalah 3 detik jeda, 6 detik kelas 0, 3 detik jeda, 6 detik kelas 1, dan diulangi hingga tiga kali sehingga dalam satu kali sesi perekaman diperlukan waktu sebanyak 54 detik. Sebagai contoh, pada Gambar 6 ditunjukkan hasil perekaman pada subjek 4 yang memperhatikan objek berupa anak panah horisontal (kiri dan kanan) tanpa latar belakang warna (jenis PV) untuk 18 detik pertama.

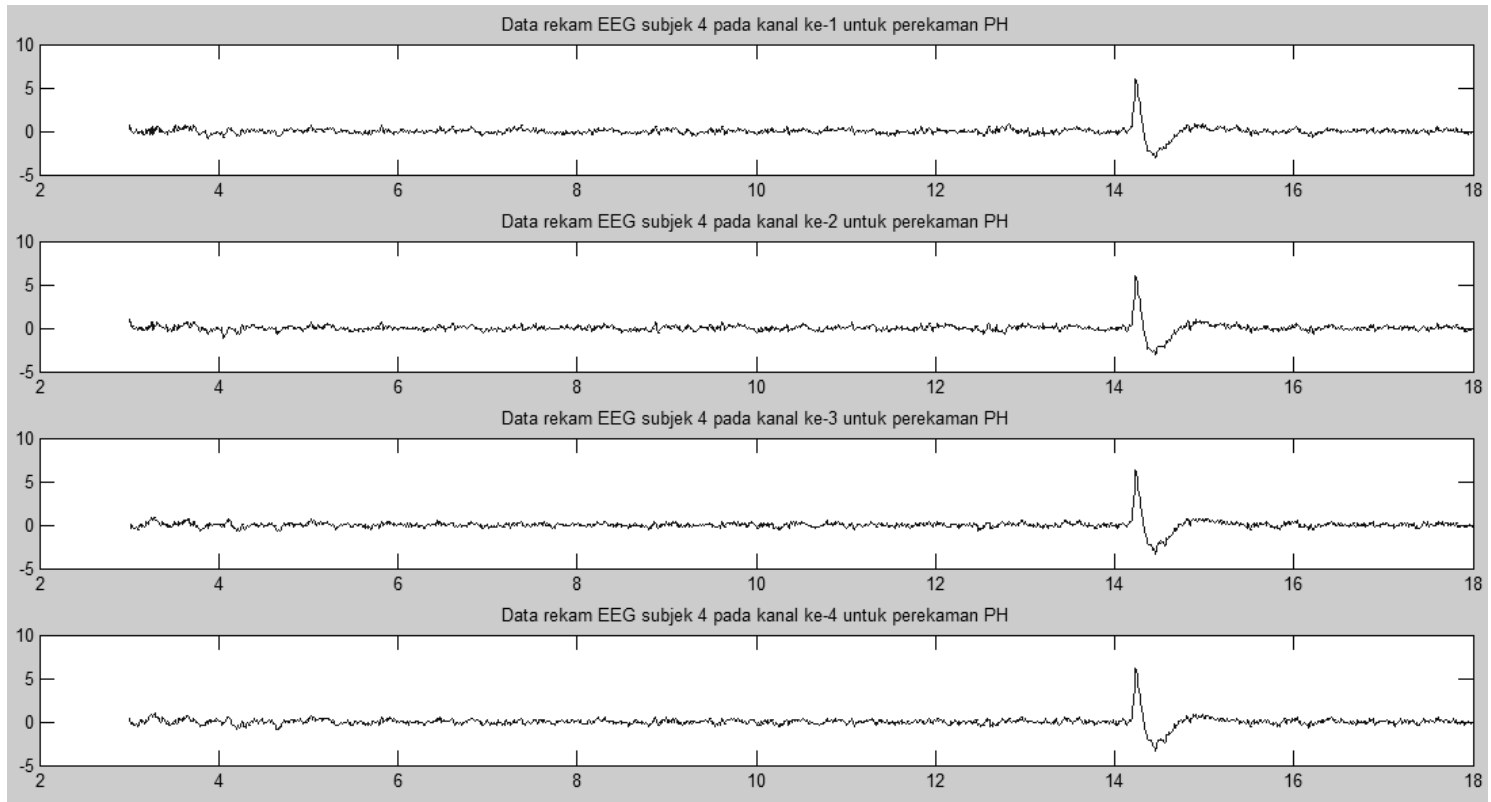

Gambar 6 Hasil data rekam EEG dari subjek 4

\subsection{Pengamatan ciri pada ranah waktu}

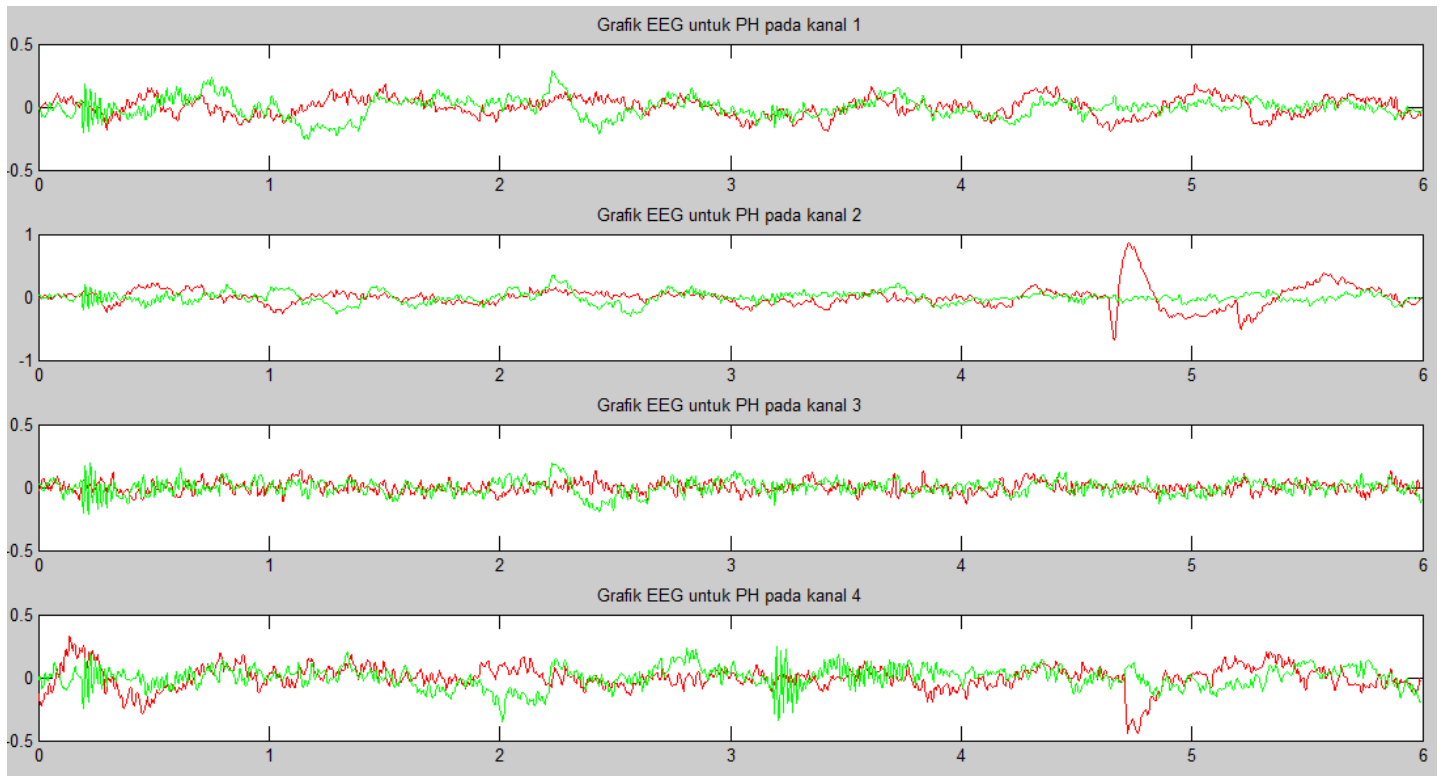

Gambar 7 Grafik EEG rerata seluruh data untuk perekaman anak panah horisontal tanpa latar belakang (merah: kelas 0; hijau: kelas 1) 
Pada Gambar 7, ditunjukkan rerata seluruh data pada kedua kelas untuk jenis data $\mathrm{PH}$ pada masing-masing kanal. Secara keseluruhan, pada kanal 1 dan kanal 2 terdapat perbedaan pola yang lebih tampak daripada pada kanal 3 dan kanal 4. Pada kanal 3, terdapat perbedaan yang lebih tampak pada detik sekitar ke-0,5 hingga detik ke-2,5, sedang pada kanal2, perbedaan lebih mencolok tampak pada mendekati detik ke-5.

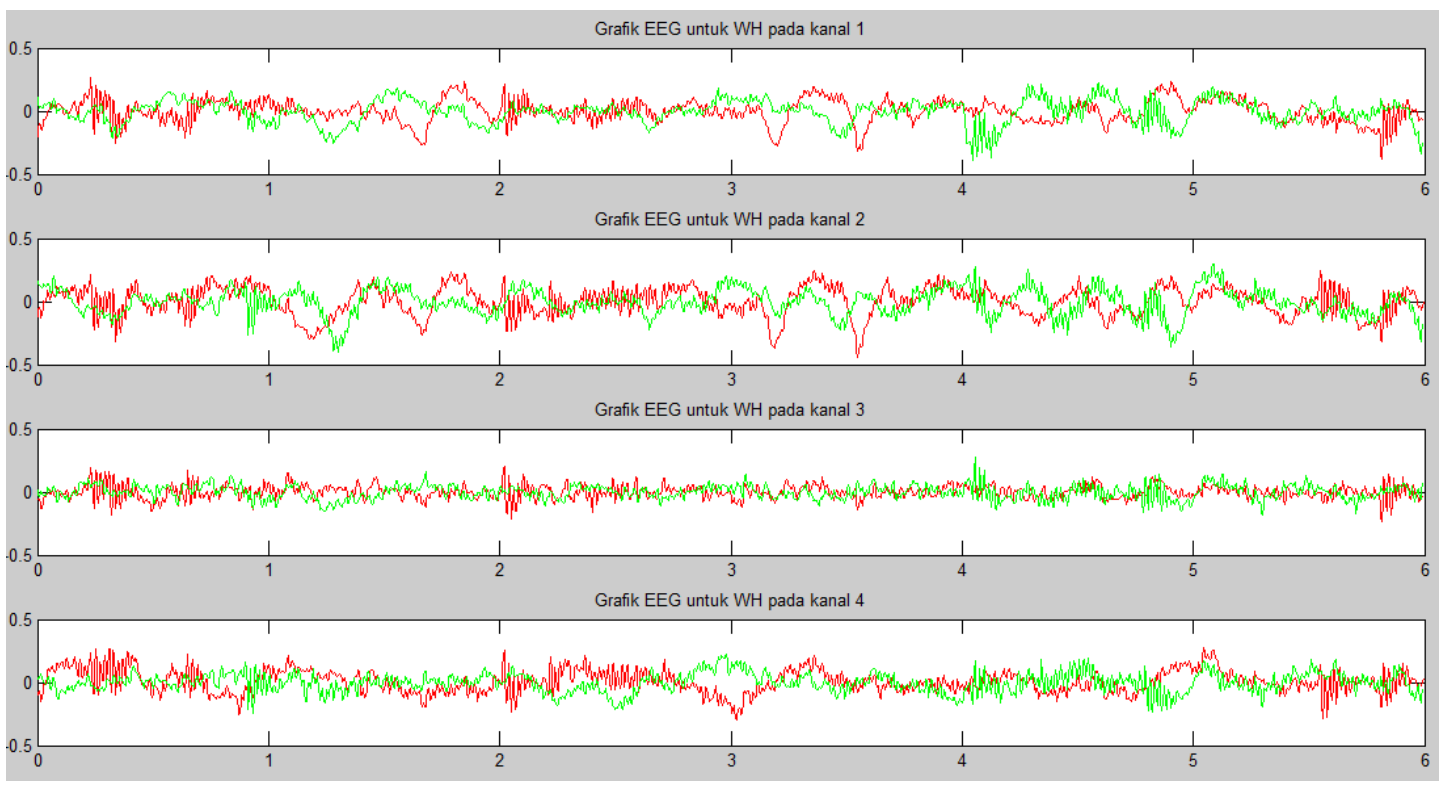

Gambar 8 Grafik EEG rerata seluruh data untuk perekaman anak panah horisontal dengan latar belakang warna (merah: kelas 0; hijau: kelas 1)

Pada Gambar 8, dengan latar belakang warna, tampak bahwa rata-rata dari seluruh subjek mengalami variansi data pada kanal 1 dan 2 dimana kanal tersebut sangat dekat dengan lokasi mata. Data tersebut mungkin muncul akibat dari perubahan latar belakang warna terhadap aktivitas mata.

\subsection{Pengamatan ciri pada ranah frekuensi}

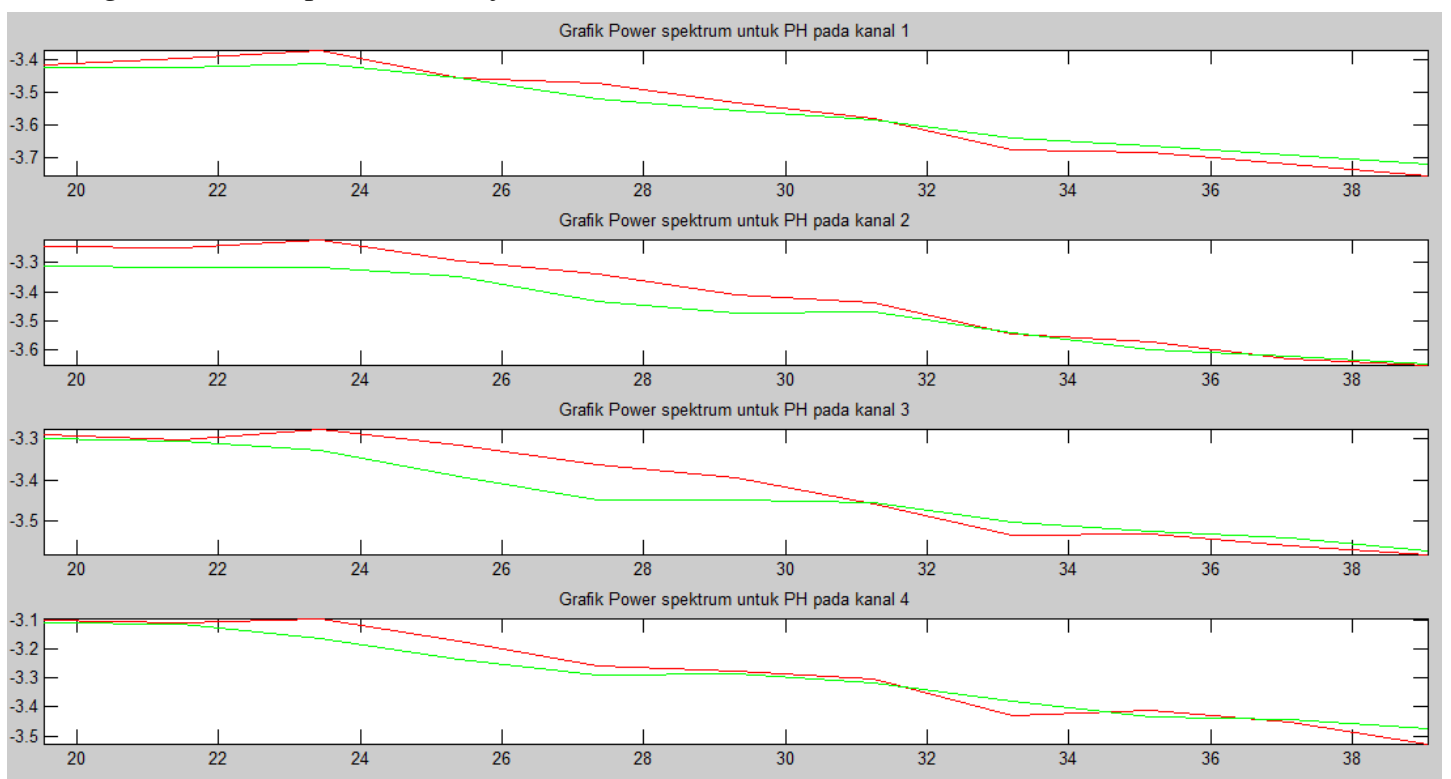

Gambar 9 Spektrum frekuensi rerata seluruh data untuk perekaman horisontal tanpa latar belakang warna (merah: kelas 0; hijau: kelas 1) 
Salah satu komponen yang penting untuk diamati dalam gelombang EEG adalah komponen frekuensi. Pada dasarnya, frekuensi gelombang EEG sangat berkaitan dengan aktivitas dari seseorang. Pada penelitian yang pernah dilakukan Blankertz, disimpulkan bahwa frekuensi yang patut diamati untuk sebuah fokus klasifikasi berada pada frekuensi tinggi, sampai pada $40 \mathrm{~Hz}[11]$.

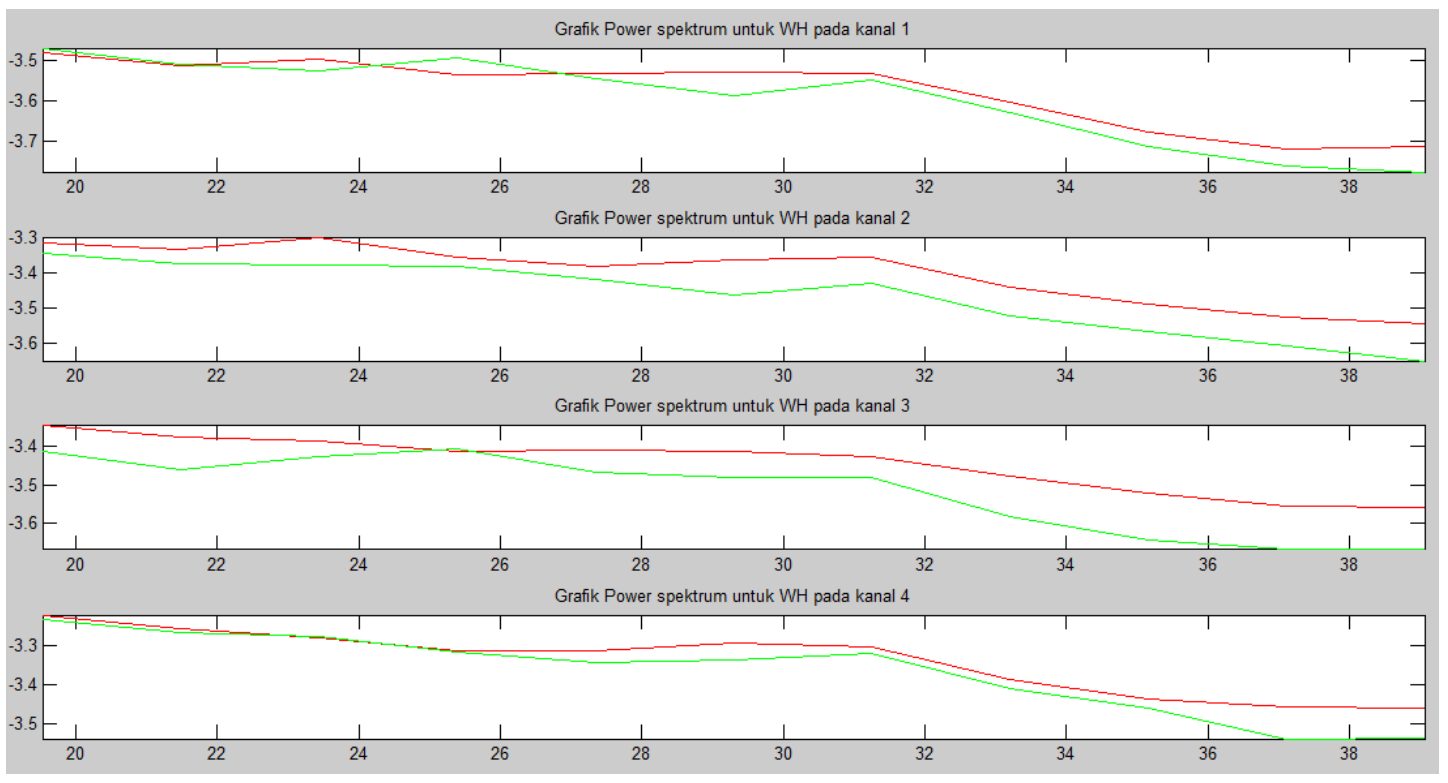

Gambar 10 Spektrum frekuensi rerata seluruh data untuk perekaman horisontal dengan latar belakang warna (merah: kelas 0; hijau: kelas 1)

Pada Gambar 9 ditunjukkan spektrum frekuensi dari rerata seluruh data rekam EEG pada frekuensi 20 sampai $40 \mathrm{~Hz}$. Pada grafik tersebut tampak bahwa perbedaan antara kedua kelas paling mencolok terdapat pada kanal 2 dan kanal 3 pada rentang 20 hingga $30 \mathrm{~Hz}$. Sedang pada Gambar 10 ditunjukkan grafik spektrum frekuensi dari objek dengan latar belakang berwarna. Pada gambar tersebut tampak bahwa perbedaan antara kedua kelas semakin tampak pada frekuensi yang semakin tinggi, yaitu sekitar $37 \mathrm{~Hz}$. Berbeda dengan visualisasi objek tanpa latar belakang dimana perbedaan besar antara kedua kelas muncul pada frekuensi yang relatif lebih rendah, yaitu pada daerah frekuensi sekitar $28 \mathrm{~Hz}$.

\subsection{Pengujian ciri pada klasifikasi dengan jaringan syaraf tiruan}

Asumsi yang digunakan untuk menilai kualitas ciri pada penelitian ini adalah berkaitan dengan baiknya tingkat klasifikasi yang dihasilkan oleh sistem klasifikasi. Dengan menggunakan ciri ranah waktu berupa RMS dan ciri ranah frekuensi berupa PSE pada setiap kanal, masing-masing lapisan terdiri dari 8 titik pada lapisan masukan, 8 titik pada lapisan tersembunyi, dan 2 titik pada lapisan luaran seperti ditunjukkan pada Gambar 11.

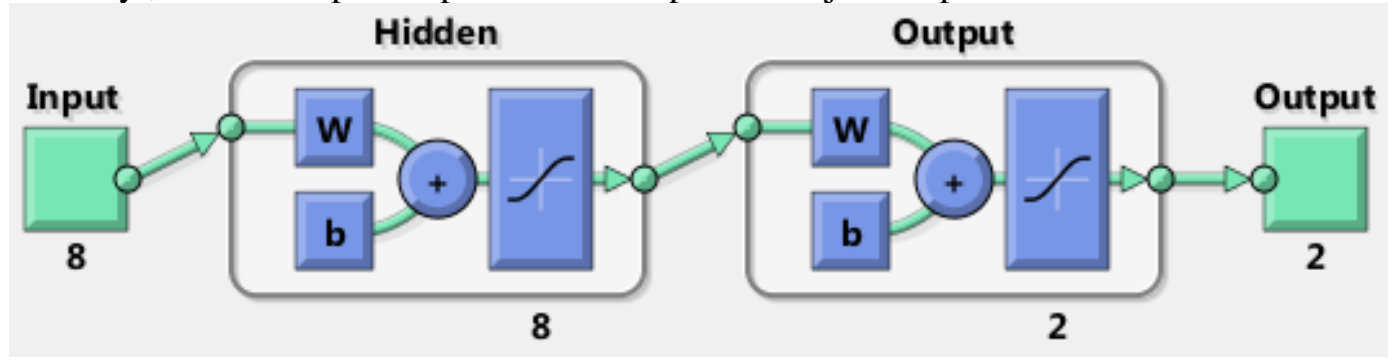

Gambar 11 Arsitektur jaringan syaraf tiruan yang digunakan 
Tabel 3 Akurasi data latih untuk setiap perekaman data

\begin{tabular}{|c|c|c|c|c|c|}
\hline \multirow{2}{*}{$\begin{array}{c}\text { Jenis } \\
\text { perekaman }\end{array}$} & \multirow{2}{*}{ Performa } & \multirow{2}{*}{ Iterasi } & \multicolumn{3}{|c|}{ Akurasi (\%) } \\
\cline { 4 - 6 } & & & Kelas 0 & Kelas 1 & Total \\
\hline PH & 0,0833 & 300 & 95,83 & 87,50 & 91,67 \\
\hline WH & 0,0870 & 271 & 87,50 & 95,83 & 91,67 \\
\hline PV & 0,0832 & 187 & 87,50 & 95,83 & 91,67 \\
\hline WV & 0,0534 & 423 & 95,24 & 95,24 & 95,24 \\
\hline
\end{tabular}

Pengujian dengan klasifikasi dilakukan pada keempat jenis objek pengujian. Pada Tabel 3, ditunjukkan rangkuman akurasi pada pelatihan klasifikasi untuk setiap kelompok data. Data yang ditampilkan merupakan data terbaik dari beberapa pelatihan pada sistem jaringan syaraf tiruan. Pada tabel tersebut tampak bahwa secara keseluruhan, tidak tampak perbedaan yang signifikan yang berarti bahwa latar belakang warna tidak memberikan pengaruh signifikan terhadap pelatihan pada sistem klasifikasi dengan jaringan syaraf tiruan.

Tabel 4 Pengujian setiap data latih terhadap seluruh data rekam

\begin{tabular}{|c|c|c|c|c|c|}
\hline \multicolumn{2}{|c|}{ Jenis data latih } & \multicolumn{3}{|c|}{ Akurasi } & \multirow{2}{*}{$\begin{array}{c}\text { Banyak } \\
\text { data }\end{array}$} \\
\hline Latih & $\mathbf{U j i}$ & Kelas 0 & Kelas 1 & Total & \\
\hline \multirow{5}{*}{$\mathrm{PH}$} & $\mathrm{PH}$ & 95,83 & 87,50 & 91,67 & 48 \\
\hline & WH & 37,50 & 66,67 & 52,08 & 48 \\
\hline & $\mathrm{PV}$ & 50,00 & 41,67 & 45,83 & 48 \\
\hline & WV & 57,14 & 38,10 & 47,62 & 42 \\
\hline & TOTAL & 60,22 & 59,14 & 59,68 & 186 \\
\hline \multirow{5}{*}{ WH } & $\mathrm{PH}$ & 70,83 & 29,17 & 50,00 & 48 \\
\hline & WH & 87,50 & 95,83 & 91,67 & 48 \\
\hline & $\mathrm{PV}$ & 50,00 & 70,83 & 60,42 & 48 \\
\hline & WV & 52,38 & 52,38 & 52,38 & 42 \\
\hline & TOTAL & 65,59 & 62,37 & 63,98 & 186 \\
\hline \multirow{5}{*}{ PV } & $\mathrm{PH}$ & 25,00 & 50,00 & 37,50 & 48 \\
\hline & $\mathrm{WH}$ & 33,33 & 58,33 & 45,83 & 48 \\
\hline & $\mathrm{PV}$ & 87,50 & 95,83 & 91,67 & 48 \\
\hline & $\mathrm{WV}$ & 52,38 & 47,62 & 50,00 & 42 \\
\hline & TOTAL & 49,46 & 63,44 & 56,45 & 186 \\
\hline \multirow{5}{*}{ WV } & $\mathrm{PH}$ & 54,17 & 50,00 & 52,08 & 48 \\
\hline & $\mathrm{WH}$ & 41,67 & 58,33 & 50,00 & 48 \\
\hline & $\mathrm{PV}$ & 45,83 & 50,00 & 47,92 & 48 \\
\hline & WV & 95,24 & 95,24 & 95,24 & 42 \\
\hline & TOTAL & 58,06 & 62,37 & 60,22 & 186 \\
\hline
\end{tabular}

Untuk menentukan kesuksesan sistem yang dilatih dengan ciri pada setiap jenis perekaman data, dilakukan pengujian sistem yang terlatih dengan data uji dari seluruh data rekam. Rangkuman hasil pengujian tersebut ditunjukkan pada Tabel 4.

Pada Tabel 4, tampak setiap jenis data latih diujikan ke jenis data lain sebagai data uji. Secara keseluruhan, yaitu keberhasilan setiap jenis data latih mengenali semua data, akurasi 
ditampilkan pada baris TOTAL. Pada tabel tersebut terlihat bahwa jenis data WH, yaitu pelatihan dengan subjek arah horizontal dengan latar belakang berwarna memiliki akurasi total terbaik, yaitu mencapai $63,98 \%$, sedang jenis data WV mencapai tingkat akurasi sebesar $60,22 \%$. Jika diambil batas akurasi $50 \%$ sebagai batas bawah, maka terlihat pada tabel (yang diberi tanda tebal) bahwa jenis data latih WH mampu mengenai lebih banyak jenis data uji dibanding jenis data latih yang lain.

Dari hasil pengujian ciri dengan menggunakan suatu klasifikasi jaringan syaraf tiruan tersebut, tampak perbedaan sistem klasifikasi yang dihasilkan. Meskipun perbedaan hasil klasifikasi terhadap jenis data uji dari kelompok lain tidak lebih dari $8 \%$ secara keseluruhan, namun hal ini menunjukkan hasil yang lebih baik. Dari hasil tersebut tampak bahwa memang latar belakang warna pada objek tak berwarna untuk suatu sistem pelatihan memberikan ciri yang lebih bagus daripada objek tak berwarna tanpa latar belakang warna yang dapat dikarenakan pilihan warna yang kontrast antara kedua kelas objek mengganggu fokus subjek pada objek yang diamati.

\section{KESIMPULAN}

Dari hasil penelitian yang telah dilakukan, diperoleh beberapa kesimpulan sebagai berikut

1. Pelatihan BCI dengan objek visual berupa gambar tak berwarna dengan latar belakang warna menghasilkan ciri yang lebih baik daripada gambar tak berwarna tanpa latar belakang warna.

2. Pengujian sistem klasifikasi pada data latih tanpa latar belakang warna dengan menggunakan data latih tidak menghasilkan hasil sistem klasifikasi yang berbeda signifikan dibanding dengan data latih dengan latar belakang berwarna.

\section{SARAN}

Berikut beberapa saran untuk penelitian selanjutnya yang terkait dengan penelitian ini

1. Penggunaan kanal yang lebih banyak untuk kemudian diamati kanal-kanal yang menghasilkan ciri terbaik

2. Pengamatan terhadap variasi warna lain pada latar belakang untuk mendapatkan warna latar belakang terbaik secara umum pada pelatihan subjek.

\section{DAFTAR PUSTAKA}

[1] Sanei, S. and Chambers, J.A. (2007) EEG Signal Processing. John Wiley \& Sons Ltd., West Sussex.

[2] Juozapavicius, A., Bacevicius, G., Bugelskis, D. and Samaitiene, R. (2011) EEG Analysis - Automatic Spike Detection. Nonlinear Analysis: Modelling and Control, 16, 375-86.

[3] Tzallas, A.T., Oikonomou, V.P. and Fotiadis, D.I. (2006) Epileptic spike detection using a Kalman filter based approach. Proceedings of the 28th IEEE EMBS Annual International Conference of the IEEE Engineering in Medicine and Biology Society, p. 501-4. https://doi.org/10.1109/IEMBS.2006.260780

[4] Nenadic, Z. and Burdick, J.W. (2005) Spike detection using the continuous wavelet transform. IEEE Transactions on Bio-Medical Engineering, 52, 74-87. https://doi.org/10.1109/TBME.2004.839800

[5] Blankertz, B., Curio, G. and Müller, K. (2001) Classifying Single Trial EEG : Towards Brain Computer Interfacing. Neural Information Processing System: Natural and Synthetic, 157-64.

[6] Hill, N.J., Lal, T.N., Bierig, K., Birbaumer, N. and Scholkopf, B. (2004) Attentional Modulation of Auditory Event-Related Potential in a Brain-Computer Interface.

Pengaruh Latar Belakang Warna pada Objek Gambar terhadap Hasil ... (Catur Atmaji) 
Proceedings of IEEE International Workshop on Biomedical Circuits \& Systems, p. 1720.

[7] Mensh, B.D., Werfel, J. and Seung, H.S. (2004) BCI Competition 2003--Data set Ia: combining gamma-band power with slow cortical potentials to improve single-trial classification of electroencephalographic signals. IEEE Transactions on Bio-Medical Engineering, 51, 1052-6. https://doi.org/10.1109/TBME.2004.827081

[8] Zakzewski, D., Jouny, I. and Yu, Y.C. (2014) Statistical Features of EEG Responses to Color Stimuli. Proceedings of 40th Annual Northeast Biomedical Engineering Conference, p. 2-3.

[9] Calibo, T.K., Blanco, J.A. and Firebaugh, S.L. (2013) Cognitive Stress Recognition. Proceedings of IEEE International Instrumentation and Measurement Technology Conference, p. 1471-5.

[10] Tello, R.J.M., Müller, S.M.T., Ferreira, A. and Bastos, T.F. (2015) Comparison of the influence of stimuli color on Steady-State Visual Evoked Potentials. Research on Biomedical Engineering, 31, 218-31.

[11] Blankertz, B., Müller, K., Curio, G., Vaughan, T.M., Schalk, G. and Jonathan, R. (2004) The BCI Competition 2003: Progress and Perspective in Detection and Discrimination of EEG Single Trials. IEEE Transactions on Biomedical Engineering, XX, 100-6.

[12] Welch, P.D. (1967) The Use of Fast Fourier Transform for the Estimation of Power Spectra: A Method based on Time Averaging Over Short, Modified Periodograms. IEEE Transactions on Audio and Electroacoust, AU-15, 70-3. 